\title{
Cross-Modal Perception IN KIRUNDi
}

\author{
Emmanuella Ahishakiye ${ }^{1,2}$ \\ ${ }^{1}$ Department of English, Institute for Applied Pedagogy- University of Burundi \\ ${ }^{2}$ Faculty of Languages, Arts and Translation- University of Liège
}

\begin{abstract}
Languages do not always use specific perception words to refer to specific senses. A word from one sense can metaphorically express another physical perception meaning. For Kirundi, findings from a corpus-based analysis revealed a cross-modal polysemy and a bidirectional hierarchy between higher and lower senses. The attested multisensory expression of auditory verb kwûmva 'hear' allows us to reduce sense modalities to two -vision and audition. Moreover, the auditory experience verb kwûmva 'hear' shows that lower senses can extend to higher senses through the use of synaesthetic metaphor (e.g. kwûmva akamōto 'lit:hear a smell'/ururírimbo ruryōshé 'lit: a tasty song'/ururirimbo ruhimbâye 'lit: a pleasant song). However, in collocations involving emotion words, it connects perception to emotion (e.g.; kwûmva inzara 'lit: hear hunger', kwûmva umunêzêro 'lit: hear happiness'). This association indicates that perception in Kirundi gets information from both internal and external stimuli. Thus, considering feelings as part of the perception system.
\end{abstract}

\section{KEYWORDS}

Sense Modality, Kirundi, cross-modal perception, lexical semantics, synaesthetic metaphor.

\section{INTRODUCTION}

This paper discusses the lexicalisation of sensory perception in Kirundi [JD62], a native language all Burundians. Burundi, being located in the East Africa at the centre of Great Lakes, some languages spoken in the neighbouring regions such as Kinyarwanda [JD61]in Rwanda, Kiha [JD66], Kihangaza [JD65], Kishubi [JD64] and Vinza [JD67] in Tanzania (Mberamihigo, 2014, p. 27) are mutually intelligible with Kirundi. Moreover, it examines the relationship and/or associations between senses. That is, the identified basic verbs will be analysed in their contexts of use for their different meanings in the physical perception domain.

\subsection{Perception Verbs}

None would deny the prominence of sensory perception in our everyday communication. Sense organs- eyes, ears, skin, mouth and nose - collect information from the outer world for us, which the language translates it into words. However, languages do not give sense perception the same importance and do not always use specific perception words to refer to specific senses. A word from one sense can metaphorically express another physical perception meaning. Languages differ in how they lexicalize the sense perception (Moravcsik, 2012) and in the number of basic verbs they use to express them(Viberg, 1983). Viberg argues that the more a language avails basic verbs for each sensory modality the less it combines more than one sense modalities into a single verb. Thus, the conflation of senses results into cross-modal meaning extensions. 
To comply with Majid \& Levinson's (2011) wish for more knowledge about how people around the world express perceptual experience, the present study deals with Kirundi sensory lexicalization patterns with focus on the semantic extensions of basic Verbs of Perception (henceforth, VoP) across sensory modalities. Although perception has attracted much attention in linguistics and cognitive sciences (e.g., A. Aikhenvald \& Storch, 2013; Evans \& Wilkins, 2000; Levinson \& Majid, 2014; San Roque et al., 2018; Sweetser, 1990; Vanhove, 2008; Viberg, 1983), less is known about Kirundi. Moreover, many studies focusing on meaning extensions of perception words and the various meanings paid more attention on transfield polysemy(Evans \& Wilkins, 2000; Sweetser, 1991; Vanhove, 2008) but a few on intra field polysemy (San Roque et al., 2018). As San Roque et al. claim that "Polysemy is a linguistic habit practiced by everyone, every day", this paper describes the lexicalisation of the basic senses to demonstrate crossmodality in Kirundi and their effect on Viberg's (1983) directional hierarchy of sense modalities. The significance of this study lies in enriching literature on the lexicalisation of the field of perception since universal claims (Sweetser, 1991; AAke Viberg, 1983) were criticised for not resulting from representative data. Therefore, there is still need of examining findings from typological studies on the language of perception to make sure they apply to all the worldwide language and language users.

Regarding sense modalities, Viberg's (1984) paradigm reveals that the basic VoP refer to the five Aristotelian senses-Sight, Hearing, Touch, Smell and Taste- whichhe considers as the most important semantic components of the perception field. However, there is no agreement on the number of senses to consider. Sense recognition is a culturally bound aspect. Speakers, depending on their language and their cultural background may have more than five senses (Classen, 1993) or less (Ritchie, 1991) or can join more sensory modalities together (Howes, 2006c). From the five senses, Viberg claims that vision verbs dominates and that VoP have a unidirectional hierarchy. However, not all scholars agree with it. Evans and Wilkins (2000) attests it, while A. Aikhenvald and Storch (2013) and San Roque et al. (2015)do not. To verify what holds for Kirundi, the present analysis limits itself to how Kirundi expresses perceptual experiences through verbs.

\subsection{Method and Data}

This study adopted a corpus-based approach for which corpus data are of great importance since they reflect language uses, which can be analysed both quantitatively and qualitatively. In addition, to analyse concordances of VoP from the BantUgent corpus, a construction-based approach was favoured. For a usage-based analysis, the semantics of lexical units are determined by the meaning of the constructions in which they are involved (Goldberg, 1995, 2006) taking into account both perceptual and socio-cultural aspects of the language producer (Caballero \& Paradis, 2015).

To find out how Kirundi organizes perceptual experiences, twenty-five native speakers were asked to translate Viberg's (1984:125) basic paradigm of VoP into Kirundi. These native speakers also served of reference for validation of possible uses not found in the corpus.

The grid paradigm contains fifteen sentences referring to the basic five senses (Sight, Hearing, Touch, Taste and smell) and the three semantic components (controlled perception, uncontrolled perception and the source-based perception) as Table 1 indicates it. 
Table 1: The basic paradigm of VoP (Adapted from Viberg, 1984:125)

\begin{tabular}{llll}
\hline $\begin{array}{l}\text { Dynamic } \\
\text { system: }\end{array}$ & $\begin{array}{l}\text { Base selection: } \\
\text { Activity }\end{array}$ & $\begin{array}{l}\text { Experience r-based } \\
\text { Experience } \\
\text { (state/inchoactive) }\end{array}$ & $\begin{array}{l}\text { Source-based } \\
\text { Copulative (State) }\end{array}$ \\
\hline $\begin{array}{l}\text { Sense } \\
\text { modality }\end{array}$ & $\begin{array}{l}\text { Peter was looking/ looked at } \\
\text { the birds. }\end{array}$ & Peter saw the birds. & Peter looked happy \\
\hline Sight & $\begin{array}{l}\text { Peter was listening/ listened to } \\
\text { the birds. }\end{array}$ & Peter heard the birds. & Peter sounded happy \\
Pearing & $\begin{array}{l}\text { Peter was feeling/ felt the cloth. } \\
\text { /to see how soft it was/ }\end{array}$ & $\begin{array}{l}\text { Peter felt a stone under } \\
\text { his foot. }\end{array}$ & The cloth felt soft \\
Peter was tasting/tasted the & $\begin{array}{l}\text { Peter tasted garlic in the } \\
\text { food. }\end{array}$ & $\begin{array}{l}\text { The food tasted good/bad/of } \\
\text { garlic. }\end{array}$ \\
/to see if he could eat it/ & $\begin{array}{l}\text { Peter was smelling/smelled the } \\
\text { cigar. }\end{array}$ & $\begin{array}{l}\text { Peter smelled cigars in } \\
\text { the room. }\end{array}$ & $\begin{array}{l}\text { Peter smelled } \\
\text { good/bad/cigars. }\end{array}$ \\
\hline
\end{tabular}

\section{/ /test frame}

As of the corpus used for this study, it contains raw materials compiled from 1485 files containing both spoken and written language productions. A concordance of BantUgent Kirundi corpus using Wordsmith Tools (Scott, 2016) yielded a wordlist of 3567037 tokens. Referring to both the distribution of the basic VoP and their uses, the analysis of VoP constructions gives an in-depth description of how Kirundi users express the basic perceptual experiences and, the linguistic and cognitive mechanisms that allow perception lexicalisation intra- and trans-modal meaning extensions.

\section{BASic Verbs of Perception In Kirundi}

In this section, the discussion focusses on the different translations of Viberg's grid frames. Examination of translations from the twenty-five participants shows that the fifteen English sentences in the grid paradigm correspond to thirty sentences in Kirundi. The difference in lexicalizing perceptual experiences between Kirundi and English finds motivation from the fact that Kirundi can count more than one verbs for each of the provided English olfactory, gustatory and tactile perception events. For the perceived-oriented event, all the provided events translates into more than one verbs. 
Table 2: Basic Verbs of Perception in Kirundi

\begin{tabular}{|c|c|c|c|c|}
\hline & & Perceiver-oriented & \multirow{2}{*}{\multicolumn{2}{|c|}{$\begin{array}{l}\begin{array}{l}\text { Perceived-Oriented } \\
\text { (Phenomenon) }\end{array} \\
\text { Copulative }\end{array}$}} \\
\hline $\begin{array}{l}\text { Sensory } \\
\text { modality }\end{array}$ & Activity & Experience & & \\
\hline Vision & Kurāba/LOOK1 & Kubóna/ SEE & \multicolumn{2}{|c|}{$\begin{array}{l}\text { Gusa/LOOK2 } \\
\text { Kubóneka/SEE+STAT } \\
\text { Kunêzzêrwa */BE HAPPY }\end{array}$} \\
\hline Hearing & $\begin{array}{l}\text { Kwûmviriza / } \\
\text { HEAR+APPL+APPL+CAUS }\end{array}$ & \multirow[t]{3}{*}{$\begin{array}{l}\text { Kwûmva / } \\
\text { HEAR }\end{array}$} & \multirow[b]{4}{*}{ 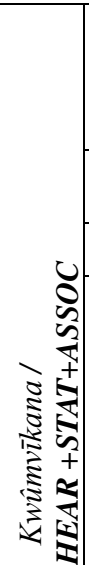 } & $\begin{array}{l}\text { Gusa/SOUND } \\
\text { Kuvúga/SOUND } \\
\text { Kunêzzērwa * / BE } \\
\text { HAPPY }\end{array}$ \\
\hline Touch & $\begin{array}{l}\text { Gukórakora/TOUCH-REDUPL } \\
\text { Gukora (ku)/Touch (on) }\end{array}$ & & & Kwôroha*/BE SOFT \\
\hline Taste & Guhônja/TASTE & & & Kuryôha*/BE TASTY \\
\hline Smell & $\begin{array}{l}\text { Kwîmotereza/ } \\
\text { REFL+SMELL } \\
\text { good+APPL+CAUS } \\
\text { Kwînükiriza } \\
\text { REFL+SMELL } \\
\text { bad+APPL+APPL+CAUS } \\
\text { Kumōtera/SMELL } \\
\text { SMELL+APPL }\end{array}$ & $\begin{array}{l}\text { Kumōterwa } \\
\text { SMELL } \\
\text { good }+A P P L+P A S S \\
\text { Kunūkirwa } \\
\text { SMELLbad }+A P P L+P A S \\
\text { S }\end{array}$ & & $\begin{array}{l}\text { Kumōta /SMELL } \\
\text { good } \\
\text { Kunuka/SMELL bad }\end{array}$ \\
\hline
\end{tabular}

Taking into consideration of the translations of the grid and the language uses from the corpus, Table 2displays basic verbs that encode both perceiver-oriented and perceived-oriented perception events in Kirundi. In the following sub-sections, usage-based from the corpus illustrates the basic VoP in context per sense modality.

\subsection{Sight}

For the experiencer-based perception, on the one hand, Kirundi distinguishes two verbs: kurāba (1) as an activity verb to mean 'Look at' and Kubóna (2) as an experience verb to express 'See'.

(1) Rāba Thomas ibigānza... (Turirimbire umukama.txt)

$\begin{array}{lll}\text { Rāb-a } & \text { Thomas } & \text { i-bi-gānza } \\ \text { IMP-to.look-FV } & \text { Thomas } & \text { AUG-NP-palm }\end{array}$

Thomas, look at the palms...

(2) Narámubônye ejó (ISA_UburundiBura_2014-10-27.txt)

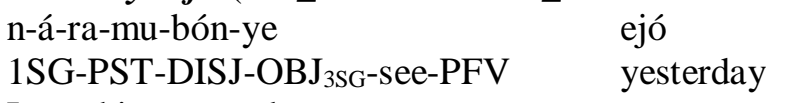

I saw him yesterday.

The source-based perception, on the other hand, the stative construction [[kubóna]V -ik-] $\mathrm{V}=[\mathrm{x}$ can be seen] is used to mean ' (not) visible, can be seen'.

(3) agakôko katabonéka (Inyigisho zijanye n'inyifato.txt)

a-ka-kôko ka-ta-bón-ik-a

AUG-NP-animal 3SG-NEG-see-STAT-IMPFV

An invisible animal.

(4) [...], birabóneka, [...]. (IragiNdanga.txt)

[...], bi-ra-bón-ik-a,[...] 


\section{[...] 3PL-DISJ-see-STAT-IMPFV, [...]}

\section{[...], you can see them, [...].}

Unlike kubóneka, whichexpresses what everybody can see, Gusa, which translates into 'look', indicates cases of truth relativity. i.e, the validity of the beauty involved in statement (5) needs to be confirmed.

\section{(5)[...], zigasa nêzá (Ndayikeza_IntaraKama.txt) \\ [...], zi-ka-se-a na-īzá \\ [...], 3PL-PRST-look-IMPFV CONJ-nice}

[...], they look nice.

Kirundi can also express the English construction V+Adj 'look happy' into only one word kunêzērwa 'be happy'(6)

(6) ntāshe nêzzerewe (Akanovera.txt)
n-tāh-ye
n- nêzēr-w-ye
1SG-go.back.home-PFV
1SG-please-PASS-PFV
I go back home being happy.

However, the construction kubóneka $+n k a$ 'as though' (lit. 'seems/appears as ifflook like') or express lack of evidence and certainty in the speaker's proposition (7)-(8).

(7) aboneka nk'ǔnēzerewe

$$
\begin{aligned}
& \text { a-bón-ik-a } \\
& \text { 3SG-see-STAT-IMPFV } \\
& \text { He looks/seems happy. }
\end{aligned}
$$

nka u-u- nêzēr-w-ye

$$
\text { as.though REL-3SG-please-PASS-PFV }
$$

(8) muboneka nk'âbâna (RPA_Ntusamare.txt)

$\begin{array}{lll}\text { mu-Ø-bón-ik-a } & \text { nka } & \text { a-ba-âna } \\ \text { 2PL-PRS-see-STAT-IMPFV } & \text { as.though } & \text { AUG-NP-child }\end{array}$

You look like babies [to me]

\subsection{Hearing}

The classification of the basic VoP in Kirundi showed that kwûmval HEAR conveys an uncontrolled perception (9), where the perceiver is an experiencer.

(9) Ntâbarezi [...] yūmva ingoma (L'arbre mémoire.txt)
Ntâbarezi
[...]
a-a-ûmv-a
i-n-goma
Ntâbarezi [...]
3SG-PST-to.hear-FV
AUG-NP-drum
Ntâbarezi heard rhythmic beats of drums.

To express a controlled auditory perception, two derived verbs Kwûmviriza (10) andkwûmvīra (11) are alternatively used for the same concept "to listen" without changing the meaning of the constructions in which they are involved.

(10) Ndûmviriza [...]. (Amazaburi 2.txt)

n-ra-ûmv-ir-ir-i-a

1SG-DISJ-to hear-APPL-APPLCAUS-IMPFV [...]

I listen to [God's word].

(11) Umvira [...] (Abatagatifu bashasha.txt)

$$
\text { ûmv-ir-a [...] }
$$

IMP-to.hear-APPL

Listen to [one of them; he is going to tell us about it]. 
However, when used in an intransitive construction (12-13), the verb kwûmva expresses '(lack of) ability to hear'.

(12) [...] amatwí yūmvá n'âmâso aboná. (Impanuro.txt)
$[\ldots]$
a-ma-twi
$a-\hat{u} m v-a$
na
a-ma-iso a-bón-a
AUG-NP-ear REL-3PL-to.hear-FV and
AUG-NP-eye REL-to.see-FV

[...] receptive ears and keen eyes.

(13) [...] umūntu atūmvá kăndi w'íkiragi. (UbwuzureBushasha.txt)

$\begin{array}{lllll}\text { u-mū-ntu } & \text { a-ta-ûmv-á } & \text { kăndi } & \text { wa } & \text { í-ki-ragi } \\ \text { AUG-NP-person } & \text { REL-3SG-NEG-to.hear-FV } & \text { and } & \text { of } & \text { AUG-NP-dumb }\end{array}$

[...] a deaf and dumb person.

To express a perceived-oriented perception, speakers use a stative derivation kwûmvīkana to be heard' of the HEAR verb kwûmva as illustrated in (14) and (15).

(14) hŭmvīkanye umurǐndi (IcaGatandatu.txt)

ha-a-ûmv- ik-an-ye

LOC-PST-to.hear-STAT-ASSOC-PFV

u-mu-rĭndi

They heard a hurried sound of footsteps.

AUG-NP-hurried.sound.of.footstep

(15) [...] inyuma y'ámasásu yūmvîkanye (RPA_JP_2014-10-16.txt)

\begin{tabular}{|c|c|c|c|}
\hline $\begin{array}{l}\text { na } \\
\text { fter }\end{array}$ & $\begin{array}{l}\text { ya } \\
\text { CONN }\end{array}$ & $\begin{array}{l}\text { a-ma-sásu } \\
\text { AUG-NP-bullet }\end{array}$ & $\begin{array}{l}\text { a-a-ûmv-ik-an-ye } \\
\text { 3PL-PST-STAT-As }\end{array}$ \\
\hline
\end{tabular}

[...] after a burst of gunfire echoed

However, 'he sounded happy' can translate into 'yavúga nk'úwunêzerewe' where 'sound' corresponds to 'Kuvúga/speak/say' a SPEAK verb when the speaker, with low degree of certainty infers from how his interlocutor sounded when speaking (16).

(16) yavúga nk'ǔnēzerewe
i-á-vúg-a
nka u-u- nêzēr-w-ye
3SG-PST-speak-IMPFV
like REL-3SG-please-PASS-PFV

He sounded happy

Nevertheless, with high degree of certainty, the SPEAK verb and the conjunction $n k a$ 'like/as though/as if' are omitted as (17) shows it.

(17) Aranêzerewe

a-ra-nêzēr-w-ye

3SG-FOC-please-PASS-PFV

He is happy

Therefore, the expression of epistemic modality, using HEAR or SEE verbs, is associated with the presence/absence of source-based verbs (kubóneka 'seems/appears/look' and kuvúga 'sound') and the conjunction nka' as though/as if / like'.

It is worth mentioning that the same SPEAK verb kuvúga can convey the speaker's report of a hearsay (that he heard something being talked about). The passive form (18) of verb is used, read as 'say/mention'.

(18) murí abo haravúgwa umushîngamátēká Bernard Busokoza ... (IGIHE140331Uprona.txt)

murí abó ha-ra-vúg-u-a u-mu-shîngamátēká Bernard

Busokoza

among them LOC-DISJ-say-PASS-FV

AUG-NP-member.of.parliament

Bernard

Busokoza 
The Honourable Bernard Busokoza is said to be among them. Or, Among them, people mention the Honourable Bernard Busokoza.

\subsection{Touch}

In Kirundi, there are two verbs for a controlled tactile perception: Gukóra $+k u$ (V+Prep) 'Touch' and its deverbative form Gukórakora'TOUCH-REDUPL'.
(19) Aca azikora ku mâso. (UbwuzureBushasha.txt)

$\begin{array}{llll}\text { a-cî-a } & \text { a-zi-kór-a } & \text { ku } & \text { ma-îso } \\ \text { 3SG-immediately-IMPFV } & \text { 3SG-OBJ }_{3 P L} \text {-touch-IMPFV } & \text { on } & \text { NP-eye }\end{array}$

He touched their eyes.

The preposition $\mathrm{ku}$ 'on/at' can attach to the verb as a post verb enclitic (20) when the object is marked in the verb ( $V$-LOC construction).
(20)
Kó ndagukorakó ugasīmba, [...] (Giswicinobera.txt)
Kó n-ra-ku-kór-a-kó u-ka-sīmb-a, [...]
That 1SG-DISJ-OBJ ${ }_{2 S G}$-touch-LOC 2SG-PRST-jump-IMPFV

Why do you get agitated when I touch you? [...].

Derivation is not the only morphological process that Kirundi uses to create lexical perception verbs. It also uses reduplication of a verb stem to show intensity or durativity (21) with the frame Ito see how soft $x$ is/, where the reduplicated form reads 'feel'. The reduplicated root has an aspectual semantic value and so, adds an atelic meaning to the construction.

$$
\begin{aligned}
& \text { Pētéro yarákorakoye impǔzu. (adapted from the grid) } \\
& \begin{array}{ll}
\text { Pētéro } & \text { a-á-ra-kórakor-ye } \\
\text { Pētéro } & \text { 3SG-PST-DISJ-touch.repeatitively-PFV }
\end{array}
\end{aligned}
$$$$
\text { i-n-hǔzu }
$$

AUG-

NP-cloth

Peter felt the cloths/ to see how soft $x$ is/.

As of the passive tactile perception, Kirundi does not have a separate verb to express it. To fill in the gap, the language associate the uncontrolled HEAR verb with TOUCH (22).

Pētéro yumvise impǔzu imukozeko

Pētéro a-á- ûmv-ye

Pētéro 3SG-PST-hear-PFV i-n- hǔzu i-Ø-mu-kór-ye-kó

$A U G-N P$-cloth $3 S G-P R S-O B J_{3 S G}$-touch-PFV-

$L O C$

Peter felt the cloth touching him.

The source-based perception is expressed by the verb kwôroha 'be soft', which can be replaced by any other verb related to touch.

(23) Naho yoba ari impǔzu yōróshe, [...] (Burundi_Culture_Nord-Est.txt)

$\begin{array}{lllll}\mathrm{Ni} & \text { a-ha-ó } & \text { i-oo-bā } & \text { a- } Ø \text {-ri } & \text { i-n- hǔzu } \\ C O P & A U G-N P-D E M & 3 S G-M O D-B E & 3 S G-P R S-B E & \text { AUG-NP-cloth } 3 S G-P R S \text { - }\end{array}$

be.soft.PFV 
Even if it would be a soft cloth, $[\ldots]$

\subsection{Taste}

The gustatory sense modality has only one active verb Guhônja (24) "to taste a small quantity of sth or to give a small quantity of something to taste to somebody" to express a controlled gustatory perception and an evaluative verb kuryôha 'be tatsy' (25), which can be replaced by any evaluative gustatory verb. The can be verbs describing the different kind of taste such as kubîha 'have an unpleasant taste', kubába 'have a spicy taste', kugāsha 'go bad', gusôsa 'have a sweet taste', kurura 'have a sour taste', etc.

(24) Ivyárivyó vyöse azōza avyîremētse abaríyo abahǒnje. (Marriage Didier \& Annick-2019.txt)

\begin{tabular}{|c|c|c|c|}
\hline \multirow[b]{2}{*}{ Ivyárivyó } & & & \multirow[b]{2}{*}{ a- bi-îremēk-ye } \\
\hline & bi-öse & $a-z \bar{O}-\partial z-a$ & \\
\hline Whatever & PP-all & 3SG-FUT-to.come & 3SG-to.carry.on.one's.head-PFV \\
\hline $\begin{array}{l}\text { a-ba-rí-yo } \\
\text { AUG-3PL-t }\end{array}$ & & $\begin{array}{l}\text { a-ba-hônj-e } \\
\text { 3SG-3PL-to.taste-IPFV }\end{array}$ & $\begin{array}{l}\text { ba-ûmv-ir-ir-i-e } \\
\text { 3PL-to.hear-APPL-APPL-CAUS-IPFV }\end{array}$ \\
\hline
\end{tabular}

However it may be, she will bring them a small quantity (of potatoes) so that they can taste them

(25) Ziraryôshe cāne. (RPA_Akayabagu_Claude_Irengarenga.txt)

Zi-ra-ryôh-ye cāne

3PL-DISJ-be.tasy-PFV a.lot

They are very tasty.

To express uncontrolled perception, the hearing verb kwûmva is involved (26).

(26) Igihümba twūmvîsha uburyŏhe (Inyigisho menyeshantara 2.txt)

i-ki-hĭmba tu-ûmv-ish-a u-bu-ryôh-e

AUG-NP-part 2PL-to.hear-INST-FV AUG-NP-to.be.tasty-FV

A body part with which we taste.

\subsection{Smelling}

Apart from the Hearing verb Kwǔmva, which can be used with nouns denoting smell, the evaluative verb Kumōta and its derivational forms kumoterwa and kumotereza respectively express source-based, non-controlled and controlled perceptions. We realize that Kirundi distinguishes good from bad smell. The latter brings in another set of verbs kunūka, kunūkirwa and kwînukiriza. Consequently, SMELL is the sense modality that has a larger number of basic verbs.

(27) amasábuné amōta [...] (USCRI_H_Asthma.txt)

a-ma-sabuni a-Ø-mōt-a [...]

AUG-NP-soap 3PL-PRS-smell.good-IMPFV

Sweet-smelling soaps $[\ldots]$

(28) Ya mbwa imotewe, [...] ( Dusome4.txt)

i-i-á n-bwa i-mōt-ir-w-e

AUG-PP-DEM NP-dog 3SG-smell.good-IMPFV

When the dog got a sweet smell, [...]

(29) [...], kwîmōtereza.( Inyigisho menyeshantara 4.txt) 
Ku-i-mōt-ir-ir-i-a

INF-REFL-smell.good-APPL-APPL-CAUS-IMPFV

To smell /to see if something smells good/

(30) sinzôbá nkírimōtēra. (Karaba.txt)

I will no longer smell it

It is a derived verb form[-mōt-APPL] from kumōta 'smell', a source-based VoP, where the applicative morpheme does not add the semantic value of 'smelling $x$ for' but indicate the intension of the agent of the verb.

Although the language has different lexical verbs to encode each of all the five senses, the Table 2 reveals that the cross-modality extension of the hearing verb Kwûmva can reduce the lexicalization of perceptual experiences into two sense modalities only -SIGHT and HEARING using three basic verbs -Kurāba 'LOOK', Kubóna 'SEE' and Kwûmva 'HEAR'. The two first verbs expressing visual perception and the last for non-visual perception. A question, which arises here, is why or how could it be possible? The verb glosses (Table 2) show that the auditory verb kwûmva can extend its meaning to all non-visual perception events. In addition, depending on the degree of the experiencer's consciousness and focus in a perception event, the language creates new verbs kwûmviriza 'listen' and kwûmvīkana ' $x$ is audible' from existing ones to convey the needed interpretation. That is, to distinguish perceiver-oriented controlled from uncontrolled events or perceiver-oriented from perceived-oriented perception ones, Kirundi uses derivational verb extensions devices. Referring to the different mechanisms languages use to encode perceptual experiences (Usoniene's, 1999: 2), the examination of data shows that Kirundi uses both linguistic and cognitive means. To elaborate on this, Section 3 details all the linguistic means Kirundi uses to encode perception experiences.

\section{Linguistic Ways to Creating the Missing Specific VerbS}

For the linguistic means, the classification of the VoP shows that Kirundi uses both lexical and morphological means. The latter complete lexical ones to avail a perception verb where it initially did not exist. Hence, extended verbs that can express a controlled or a phenomenon-based perception within a sense modality are created. For instance, whereas the visual perception has two basic lexical forms $-k u r a \overline{b a} / \mathbf{L} \boldsymbol{O O} \boldsymbol{K}_{\boldsymbol{I}}$ and Kubóna/ SEE - to refer respectively to ACTIVITY and EXPERIENCE, the experience auditory verb Kwûmva/ HEAR needs to be attached to derivational morphemes to express an active perception (31.b). However, both visual and auditory EXPERIENCE verbs need a bound morpheme to make a copulative verb (32. a \& b). Therefore, Communicational needs in terms of perception event typology influences the language user to use either a simple lexical or a complex one by deriving a new verb from an existing one to fit in another class (Goldberg, 1995). The example is of the causative-applicative morphology, which changes a HEAR-class (31.a) into a LISTEN-class (31.b). The lexicalised verb kwîmviriza/to listen to equals a conative-intensive construction, where the implied attention of $\mathrm{X}$ to $\mathrm{Y}$ causes him to hear $\mathrm{Z}$. $\mathrm{X}, \mathrm{Y}$ and $\mathrm{Z}$ respectively referring to the listener, the speaker/interlocutor and the message.

(31) a) Pētéro yarûmvīse inyoni/.

Pētéro i-á-ra-ûmv-ye i-n-nyoni

Pētéro 3SG-PST-DISJ-to.hear-PFV AUG-NP-bird

Peter heard birds

b) Pētéro yarûmvirije inyoni/

Pētéro i-á-ra-ûmv-ye

i-n-nyoni 
NP-bird

Pētéro

Peter listened to birds.

a) Pētéro yŭmvīkana nk'úwunêzerewe

$\begin{array}{lll}\text { Pētéro } & \text { i-á-ûmv-ik-an-a } & \text { nka } \\ \text { Pētéro } & \text { 3SG-PST-to.hear-STAT-ASS-IMPFV } & \text { as.though/as if } \\ \text { u-u-nêz-ir-w-e } & & \end{array}$

u-u-nêz-ir-w-e

REL-3SG-pleasure-APPL-PASS-IMPFV

Peter sounded happy

b) Pētéro yabóneka nk'úwunêzerewe.

$\begin{array}{lll}\begin{array}{l}\text { Pētéro } \\ \text { Pētéro }\end{array} & \text { i-á-bón-ik- a } & \text { nka } \\ \text { u-u-nêz-ir-w-e } & \text { 3SG-PST-to.see-STAT-IMPFV } & \text { as.though/as if } \\ \text { L-3SG-pleasure-APPL-PASS-IMPFV } & \\ \text { er looked happy } & \end{array}$

Derivation is not the only morphological process that Kirundi uses to create lexical perception verbs. It also uses reduplication of a verb stem to show intensity or durativity (21). Thus, the present analysis shows that Kirundi, as an agglutinative language, uses derivational and reduplication morphological processes not only to express in one word what other languages would syntactically express in more than many words but also to make semantic and pragmatic nuances among perception events. Therefore, without considering the different forms of the same lexeme and that kunūka is an antonym of kumōta, Table 3 display Kirundi basic primitive VoP and their frequencies in the used corpus.

Table 3: Distribution of Kirundi VoP in the corpus

\begin{tabular}{|c|c|c|c|c|}
\hline & & Root verb & $\begin{array}{r}\text { Root Verb + } \\
\text { extensions }\end{array}$ & TOT \\
\hline \multirow[t]{3}{*}{ Vision } & Kubóna "see" & 14727 & 4208 & 1893 \\
\hline & Kurāba "look 1 " & 7221 & 196 & $\begin{array}{r}5 \\
7417\end{array}$ \\
\hline & Gusa "look2" & 152 & 0 & 152 \\
\hline Hearin & Kwûmva "hear" & 11415 & 6337 & 1775 \\
\hline & & & & 2 \\
\hline Touch & Gukora (ku)/Touch (on) & 234 & 51 & 285 \\
\hline Taste & $\begin{array}{l}\text { Guhonja "to taste/give a small quantity } \\
\text { of sth (edible/drinkable) to determine its } \\
\text { quality" }\end{array}$ & 9 & 0 & 9 \\
\hline \multirow[t]{2}{*}{ smell } & Kumōta " to smell" & 68 & 71 & 139 \\
\hline & Kumōtēra " to smell" & 3 & - & 3 \\
\hline
\end{tabular}

Figures in the above table indicate that visual and auditory perception verbs dominate in the corpus with a representation of $59 \%$ and $40 \%$ respectively. The possible order being Sight $>$ Hearing $>$ Touch $>$ Smell $>$ Taste, where SMELL interchanges the place with TASTE when compared to Viberg's directional hierarchy. This predominance in frequency of the two sense modalities Sight and Hearing in the corpus allows us to predict cross-modal meaning extension of verbs from the two sense modalities. Thus, use of cognitive means to express sensory modality. To verify this hypothesis, Section 4 discusses cross-modal meaning extensions for Kirundi VoP. 


\section{Cross-Modal Meaning Extensions}

As of the question on what cross-modal meanings Kirundi VoP can express, Table 4 gives us a picture of what verbs extend their meanings to other modalities.

Table 4: Meaning extensions to other sense modalities

Vision hearing touch smell taste

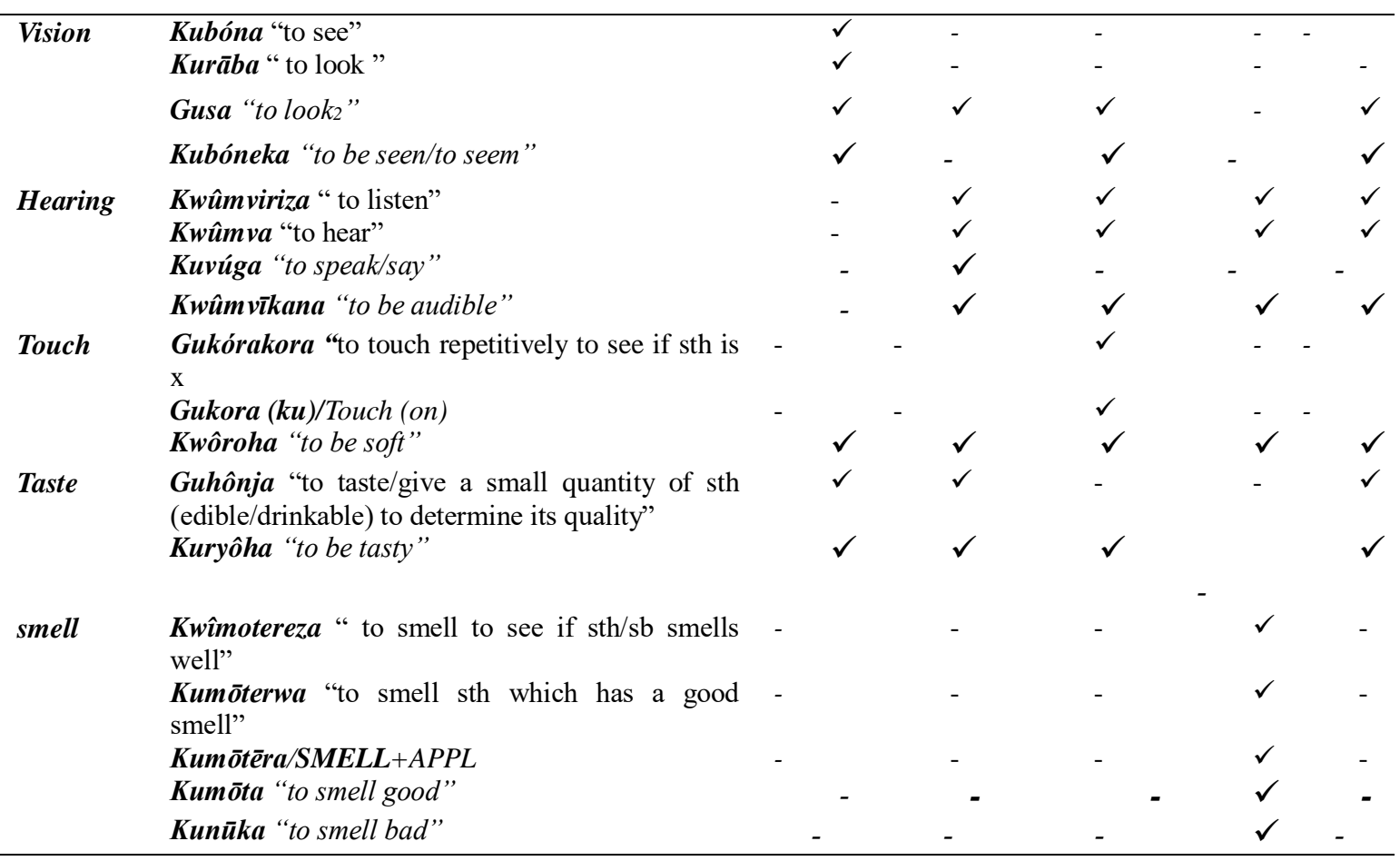

As Table 4 demonstrates it, there is difference in semantic variation in meaning extension to other sense modalities.

\subsection{Sight}

The table does not the activity visual perception verb kurāba 'to look' covering all the five sensory modalities. This is because there were no occurrences attesting meaning extensions of the verb kurāba 'to look' to other senses in the corpus. However, elicitation tests for the correctness and meaningfulness of the different constructions involving the verb kurāba allow us to deduce that kurāba/to look does not extend its meaning to all non-visual senses Instead, it bases on them to mean search for/ find by listening (33), check by touching (34) or tasting (35) and choose by smelling (36).

\begin{tabular}{|c|c|c|c|}
\hline Rāb-a & Thomas & ikásĕti & ivugá \\
\hline $\begin{array}{c}\text { IMP-to.look-FV } \\
\text { good }\end{array}$ & Thomas & AUG-NP-tape & REL-3SG-to.sound-F \\
\hline
\end{tabular}


By the end of the process, as speaker A had ordered B to look for an undamaged tape, A can ask about the result and put the question "Ni iyîhé kásěti wabōnyé(saw) ivugá nêzá? / which tape did you find undamaged?" This implies that the experience visual verb too, can extend its meaning to audition.

(34) Rāba Thomas impǔzu kó zūmyé.

$\begin{array}{llll}\text { Rāb-a } & \text { Thomas } & \text { i-n-hǔzu } & \text { ko zi-ûm-ye } \\ \text { IMP-to.look-FV } & \text { Thomas } & \text { AUG-NP-cloth that } & \text { 3PL-to.be.dry-PFV }\end{array}$

Thomas, check if cloths are thoroughly dry.

To give feedback to A, B can say it four different statements:

- "zisa n'izzumyel they look dry" when he only looked at them without feeling them and realized that there are no more drops of water from the cloths.

- "nūmva zûmye/ I feel that they are dry", which reflects an individuation of the involved perception modality (Matthen, 2015) after the speaker has touched the cloths to make sure they are thoroughly dry.

- "mbona zûmye/I see that they are dry" while touching them to verify the accuracy of the information he acquired through vision. Looking at and touching the cloths mutually certify for the cloths' dryness property, while for the last case "zirumye/they are dry" the proposal does not tell about which verification means the speaker used.

(35) Rāba Thomas indyá ká zihīyé.

$\begin{array}{lllll}\text { Rāb-a } & \text { Thomas } & \text { indyá } & \text { kó } & \text { zi-hī-yé } \\ \text { IMP-to.look-FV } & \text { Thomas } & \text { AUG-NP-food } & \text { that } & \text { 3PL-to.be.cooke- }\end{array}$

PFV

Thomas, ensure/check that the food is cooked through.

Although the alternatives "mbona zíhīye/I see that they are cooked through" and "nümva zíhīye/ I find them cooked" are also possible for the gustatory modality, "mbona/I see" does not integrate TASTE. Since the speaker only considered the food appearance without tasting them. Therefore, SEE does not base on TASTE to extend its meaning.

(36) Rāba Thomas amavúta amōtá nêzá.

$\begin{array}{llll}\text { Rāb-a } & \text { Thomas } & \text { a-ma-vúta } & \text { a-mōt-á nêzá } \\ \begin{array}{c}\text { IMP-to.look-FV } \\ \text { good }\end{array} & \text { Thomas } & \text { AUG-NP-body.lotion } & \text { REL-3SG-to.smell-FV } \\ & & & \end{array}$

Thomas, choose body lotion that has a sweet smell.

Although a transitive declarative construction mbona amavúta amōtálI see sweet body oil) was not confirmed, the non-controlled visual verb SEE can base on the olfactory sense modality to extend its meaning to 'find' by smelling in an interrogative construction (e.g: Ni ayâhé wabōnyé amōtá? Which one has a sweet smell?).

As far as perceiver oriented verbs are concerned, two verb forms - gusa look2' and Kubóneka 'can be seen'- are multimodal. Gusa "look2" in the construction Gusa nka... "Look like", the V+Prep expresses a visual percept as (37a).

(37) a) RUBERINTWARI asa nk'ǔshavuye (Nyerek'akaranga.txt)
RUBERINTWARI a-s
RUBERINTWARI 3SG-to.look like REL-3SG-to.be.unhappy/nervous-PFV 
RUBERINTWARI looks unhappy.

Depending on the context of production, the construction Gusa nka[...] can also mean, "to sound" and so refers to auditory modality. The speaker considers the mood and the words he heard from his interlocutor (RUBERINTWARI), in a conversation on telephone for instance, and infers his happiness. That is why, if he wants to specify that he inferred the happiness through what he heard, he uses the derived form "kwûmvīkana" (37c) of the verb kwûmva. Instead, in case the speaker refers to the appearance, he uses the verb Kubóneka "to seem/be seen" (37b).

b) RUBERINTWARI aboneka nk'ǔshavuye

$\begin{array}{lll}\text { RUBERINTWARI } & \text { a-bón-ik-a } & \text { nka u-shávur-ye } \\ \text { RUBERINTWARI } & \text { 3SG-to.be.seen like } & \text { REL-3SG-to.be.unhappy-IMPFV. }\end{array}$

RUBERINTWARI looks unhappy.

c) RUBERINTWARI yūmvīkana nk'ǔshavuye

$\begin{array}{llll}\text { RUBERINTWARI } & \text { a-ûmv-ik-an-a } & \text { nka } & \text { u-shávur-ye } \\ \text { RUBERINTWARI } & \text { 3SG-to.hear-NEUT-ASSOC-FV } & \text { like } & \text { REL-3SG-be.unhappy- } \\ \text { PFV } & & \end{array}$

RUBERINTWARI sounds unhappy.

Although Kubóneka "to be seen/to seem" can function as a synonym of gusa and can replace it as in Kubóneka+nka, the construction implies the involvement of the audience or a shared opinion. That is, RUBERINTWARI appears unhappy to anyone who looks at him. RUBERINTWARI's face serves as the source of evidence for the provided information. Therefore, a clause in which the physical evaluative perception where Kubóneka heads the VP has a meaning of inferred evidentiality (Aikhenvald, 2003:1). The speaker can also use these verbs to avoid confirming what he is not sure of. Once more, he uses the verb Gushávura "to be unhappy/nervous" as the main verb (19), the proposal reflects a higher degree of certainty on the part of the speaker about the stated information than in (37d). Thus, a case of epistemic modality (Usoniene, 2002).

\section{d) RUBERINTWARI arashávuye RUBERINTWARI a-ra-shávur-ye RUBERINTWARI 3SG-DISJ-shávur-ye RUBERINTWARI is unhappy.}

Once more, in Ruberintwari is unhappy, the disjunctive marker -ra- shows the focus on the information conveyed by the verb and thus, a case of epistemic modality if we follow Halliday (1970:349). In such contexts, the verb functions as an evaluative adjective. As they are many in Kirundi due to the limited number of lexical adjectives, this study does not elaborate all of them. It only focuses on those that came out from Viberg's paradigm of VoP, where the verb kuryôherwa "to be happy", for instance, emerges because the adjective happy complemented the verb "to look" in "Peter looked happy"(Viberg, 1984b:125). This is to say that there are as many evaluative verbs as many qualities speakers may attribute to things/objects or people. Although this is valuable to all the sense modalities it extends on, the gist of the construction is that the described thing/object/person lacks the targeted feature in gustatory (38b) and tactile (38a) sense modalities.

(38) b) [...] impǔzu zisa n'izirêmvye (UbwuzureBushasha.txt)
[...] i-n-huzu
zi-sa
na i-zi-rēmb-ye 


\section{AUG-NP-cloth REL-3PL-to.look like REL-AUG-3PL-to.be.soft-PFV Cloths that looked soft [but which are not].

\author{
b) urwârwá rusa n'úruryōshé \\ u-rwârwá ru-sa na u-ru-ryōh-ye \\ AUG-banana.wine REL-3SG-to.look like REL-AUG-3SG-to.be.tasty-PFV \\ Banana wine, whichappears to have a goodtaste [but which is not].
}

Consequently, this discussion reveals that the choice of one of the different constructions "Gusa nka/na..., kubóneka nka..." to mean 'looks' in the basic sentence 'Peter looks happy", depends on whether the author makes a subjective or objective evaluation (Polis, 2009:207). Moreover, only source based visual verbs can extend their meanings to all the non-visual perception verbs, except SMELL.

\subsection{Hearing}

The classification of basic VoP in Kirundi showed that kwûmva/ HEAR conveys an uncontrolled perception, where the perceiver is an experiencer. Nevertheless, HEAR predicate constructions in Kirundi do not always refer to audition. Despite the fact that all sense modalities may have lexical verbs to express them, the auditory verb can express all the other physical sense perception except sight. The section below demonstrates the multimodal feature of the verb Kwûmva. This simply means that the nose (39), the mouth (40) and the skin $(41,42)$ can hear too, but that the eye cannot.

(39) Wūmvírize utuvúta tumōtá cāne (Ndamuhevye.txt)
u- ûmv-ir-ir-i-e
u-tu-vúta tu-mōt-a
cāne
IMP-2SG-to.hear-CON-IMPFV
AUG-NP-oil REL-3PL-to.smell-FV much
Smell to make sure the oil is fragrant.

Since the verb kumōta 'smell' can go through word-formation processes to express active (kwîmōtereza) and experience (kumōterwa) verbs, kwûmva+N or kwûmva+V constructions make light verb-constructions (Jespersen, 1954) because a single derived verb can replace it. This then reveals that kumōterwa 'catch a smell of $x$ ' can replace the multiword units "Kwûmva akamōto $(\mathrm{V}+\mathrm{N})$ or kwûmva ibimôta (V+ Rel.Clause)" in an experience olfactory perception, while the same is possible for kwîmotereza in the place of kwûmviriza akamōto $(\mathrm{V}+\mathrm{N})$ or kwûmviriza ibimôta (V+Rel.Clause). If we consider the association between sensory modalities, we can also refer to these light verb constructions as synesthetic metaphor constructions (Hui, 2007; Lievers, 2015). As in Lievers' example "She has a very sweet voice" (p2), sweet (taste) connects to voice (hearing), the Kirundi verb phrases $\mathrm{V}+\mathrm{N}$ are cases of synaesthesia too. $\mathrm{V}$ stands for hearing and $\mathrm{N}$ for any noun related to smell, taste (40) or touch.

(40) Igihŭmba twūmvîsha uburyŏhe (Inyigisho menyeshantara 2.txt)

$\begin{array}{lll}\text { i-ki-hĭmba } & \text { tu-ûmv-ish-a } & \text { u-bu-ryôh-e } \\ \text { AUG-NP-part } & \text { 2PL-to.hear-INST-FV } & \text { AUG-NP-to.be.tasty-FV }\end{array}$

A part with which we taste.

For tactile perception, the verb Kwûmva "to hear" heads a VP, where the verb collocates with a word related to the tactile field. 


$\begin{array}{llll}\begin{array}{l}l \ldots . . / n-u ̂ m v-a \\ \text { bóko }\end{array} & \text { i-ki-ntu } & \text { ki-n-fát-ye } & \text { u-ku- } \\ \text { 1SG-hear-IMPFV } & \text { AUG-NP-thing } & \text { 3SG-PP }{ }_{15 G-} \text { to.hold-PFV } & \text { AUG- } \\ \text { NP-arm } & & \end{array}$

[...] I felt something holding my arm

(42) [...] nûmvisegákaze (RTNB_Ninde_2016-08-24.txt)

$\begin{array}{lll}{[\ldots]} & \text { n- ûmv-ye } & \text { ka-kár-ye } \\ {[\ldots]} & 1 \text { SG-hear-PFV } & \text { REL-3SG- be.acrid-PFV }\end{array}$

[Today, I decided to soak up the sun until] I feel it burning.

All the above constructions refers to external information that one can perceive through four sense modalities - Hearing, smell, Taste and Touch, which the auditory verb Kwûmva "to hear" can express. Although (Wierzbicka, 1980, p. 106) has vindicated that human perception finds motivation from external stimulus, Kirundi speakers' perception can result from an internal stimulus and then use the auditory verb kwûmva. Referring to Evans \& Wilkins'( 2000), we can talk of the body's ear when it comes to associating this auditory verb with emotion or feeling terms $(43 \& 44)$.

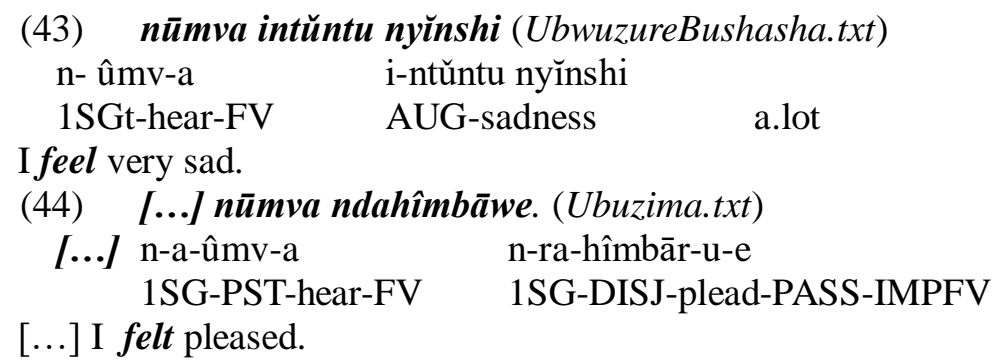

In a source-based auditory perception event, the extended verb kwîmvīkana can extend its meaning to touch, taste and smell. When words relating to the taste field combine with the verb kwǔmvikana, the construction expresses an evaluative gustatory perception event. With it, we express all what can be audible, felt, smelled or tasted. However, as of a percept expression in gustatory perception event, where the object of stimulus-based perception is the subject, the enclitic locative -mwó (inside) attaches to the derived form "kwûmvīkana" (45).

(45) umutóbe wūmvîkanamwó isúkări

$\begin{array}{lll}\text { u-mu-tóbe } & \text { u-ûmv-ik-an-a-mwó } & \text { i-súkări } \\ \text { AUG-NP-juice } & \text { REL-3SG-to.hear-STAT-ASSOC-FV-LOC } & \text { AUG-sugar }\end{array}$

A sugary juice.

Affixation plays an important role in semantic disambiguation of the different syntactic encodings of perception events in Kirundi.

\subsection{Taste}

The gustatory Guhônja, when associated with words relating to hearing or to sight fields, respectively reads 'hear a piece of $x$ ' and 'see a piece of'. Therefore, through a metonymic relationship, it conveys that the perceiver gets a small introductory part of what s/he is going to listen to or watch (46). The overall meaning of the construction is that the journalist introduces a part of the program to the followers, who will get more details later. 


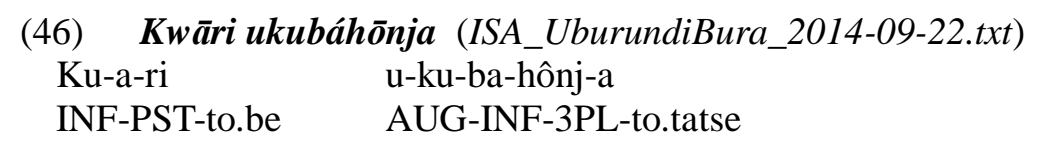

It was an introduction.

Among the considered lower senses in a Perceiver-Oriented perception event, only the gustatory verb Guhônja can extend its meaning to other sense modalities, upper sense modalities included. This verb contradicts Viberg's hypothesis about the directional hierarchy of VoP. This verb extends its meaning to both visual and auditory modalities.

As of the gustatory evaluative verb Kuryôha "to be tasty/delicious or to have taste", it can also express auditory (47a), visual (47b) and tactile (47c) perceptions.

(47) a) akūnda amajāmbo amuryŏhera (Abahungu.txt)

a-kūnd-a a-ma-jāmbo a-mu-ryôh-ir-a

3SG-to.love-IMPFV AUG-NP-word 3PL-2SG.OBJ-to.have.taste-APPL-FV

S/he likes tasteful words

b) igishóbora kuryôhera ijî̀sho [...].(Abahungu.txt)

i-ki-shóbor-a ku-ryôh-ir-a i-ri-jîsho [...]

AUG-NP-to.be.able-IMPFV INF--to.have.taste-APPL-FV AUG-NP-eye POSS

S/he will not neglect anything that can attract the boy's eye.

$$
\begin{aligned}
& \text { c) Unó mŭsi hāri akazûba karyōshé (Ninde_2020-14-01_RTNB) }
\end{aligned}
$$

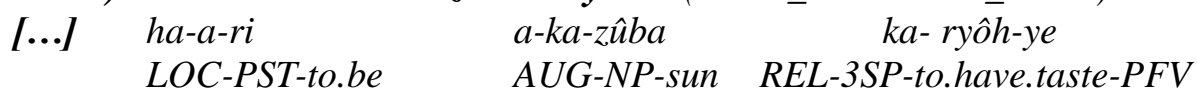

There was a warm sun today.

Again, as already discussed above, this is another case of synaesthesia. The perception event involves an association of tactile and gustatory senses. Hence, a gustatory-tactile transfer.

\subsection{Touch}

Among all the tactile perception verbs, only the tactile evaluative verb kwôroha "to be soft" can extend its uses to all the other modalities as illustrated in (48, a-d).

(48) a) Agatāmbāra kōróshe (Inyigisho menyeshantara 4.txt)

a-ka-tambara ka-ôroh-ye

AUG-NP-piece.of.cloth REL-3SG-to.be.soft-PFV

A soft piece of cloth.

With word related to sound, the verb conveys an auditory perception meaning (47b).
b) umuzikíwōróshe
i-mu-ziki
u-ôroh-ye
AUG-NP-music
REL-3PL-to.be.soft-PFV

A soft music

When the mouth is the organ of perception of the lightness/softness, especially with drinks, the evaluative verb indicates a gustatory perception (47c).

c) inzogá yōróshe 


$$
\begin{array}{ll}
\text { i-n-zoga } & \text { i-ôroh-ye } \\
\text { AUG-NP-beer } & \text { REL-3PL-to.be.soft-PFV }
\end{array}
$$

\section{Light beer}

The verb kwôroha extends to "smell" to mean a sweet smell or not a strong smell(47d).

d) parfum yōróshe

parfum

Perfume i-ôroh-ye

REL-3PL-to.be.soft-PFV

A sweet perfume (a perfume, which is not strong).

Taking into consideration the different meaning extensions, the order of Kirundi VoP reads as follows:
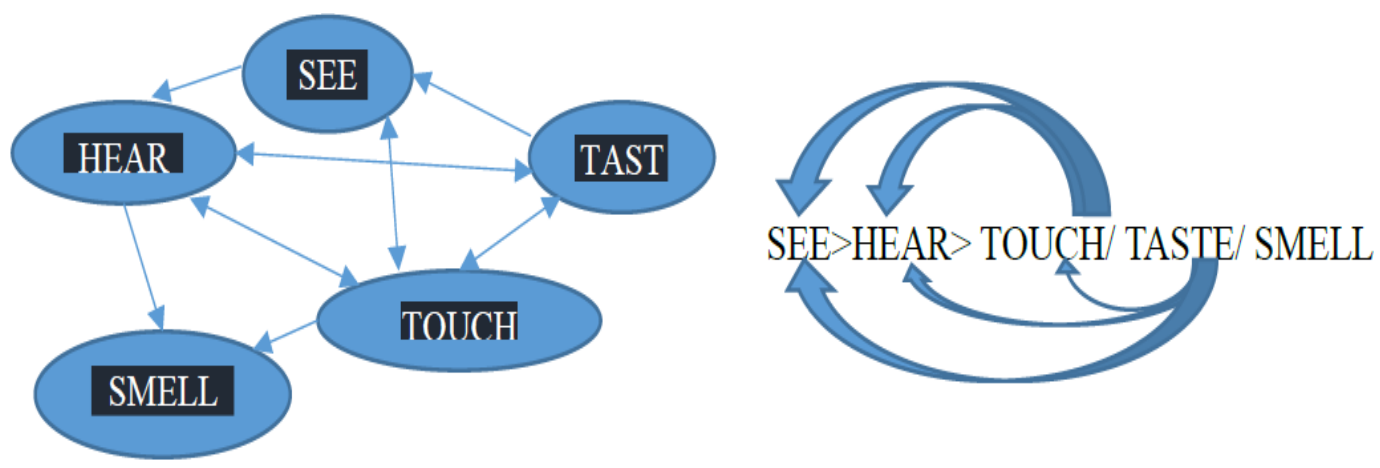

Figure 1: Cross-modal meaning extensions in Kirundi

From both perceiver and perceived-oriented angles, only SMELL cannot expend its physical meaning to other sense modalities. The hierarchy of basic VoP in Kirundi attests bidirectional relationships between some sense modalities such as SEE-TOUCH, HEAR-TOUCH, HEARTASTE and TOUCH-TASTE. That is, for Kirundi, the reverse arrows indicates a reverse relationship between the modalities, where the lower sense modality conveys a higher sense. Thus, the Viberg's VoP hierarchy does not apply to Kirundi. Regarding the two predominant senses - Sight and hearing, SEE connects to other senses through a synaesthetic simile (e.g: isa nk'iyorroshe /it looks soft) while HEAR extends its use through metaphoric synaesthesia (Kwûmviriza ităbi 'Taste cigar') and metonymy (guhônja indirimbo 'taste a song'-play or sing/listen to a short part of a song).

\section{Conclusion}

The aim of this paper was to find out the basic VoP in Kirundi, their intra field meaning extensions and the extent to which Viberg's claim on the cross-modal unidirectional hierarchy applies to Kirundi VoP. The analysis attests the use of both linguistic and cognitive means. By linguistic means, Kirundi has lexical items referring to perception(Kumōta 'SMELL', kwûmva 'HEAR'). In case of scarcity, Kirundi uses word formation patterns to derive new verbs or reduplicate the roots of the primitive verb to satisfy communication needs. Through cognitive means, the hearing verb kwûmva (and its morphologically derived forms kwûmviriza and kwûmvīkana) extends its physical meaning to non-visual senses -Touch, Taste and Smell -using metonymy or metaphor. Moreover, Kirundi verbs of audition distinguish external from internal world information. Possibly that this poly functionality is not only cross modal. A hypothesis 
that needs examination is that, as in other languages, Kirundi VoP can express different domains other than perception. Therefore, further studies would focus on cross-field meaning extensions.

\section{REFERENCES}

1. Aikhenvald, A., \& Storch, A. (2013). Perception and cognition in language and culture (Vol. 3). Brill.

2. Aikhenvald, A. Y. (2003). Evidentiality in typological perspective. Typological Studies in Language, 54, 1-32.

3. Caballero, R., \& Paradis, C. (2015). Making sense of sensory perceptions across languages and cultures. Functions of language, 22(1), 1-19.

4. Classen, C. (1993). Worlds of sense: Exploring the senses in history and across cultures. Routledge.

5. Evans, N., \& Wilkins, D. (2000). In the mind's ear: The semantic extensions of perception verbs in Australian languages. Language, 546-592.

6. Goldberg, A. E. (1995). Constructions : A construction grammar approach to argument structure. University of Chicago Press.

7. Goldberg, A. E. (2006). Construction grammar. Encyclopedia of cognitive science.

8. Halliday, M. A. (1970). Functional diversity in language as seen from a consideration of modality and mood in English. Foundations of language, 322-361.

9. Howes, D. (2006a). Charting the sensorial revolution. Taylor \& Francis.

10. Howes, D. (2006b). Cross-talk between the senses. Taylor \& Francis.

11. Howes, D. (2006c). Hearing scents, tasting sights: Toward a cross-cultural multi-modal theory of aesthetics. Science, 27, 29.

12. Hui, Y. B. Z. (2007). Cross-modal Perception and Synaesthetic Adjectives. Foreign Language Education, 1, 3.

13. Jespersen, O. (1954). A Modern English grammar, vol. 4. New York: Barnes and Noble.

14. Levinson, S. C., \& Majid, A. (2014). Differential ineffability and the senses. Mind \& Language, 29(4), 407-427.

15. Lievers, F. S. (2018). Synaesthesia and Other Figures. What the Senses Tell Us About Figurative Language. In Sensory Perceptions in Language, Embodiment and Epistemology (p. 193-207). Springer.

16. Majid, A., \& Levinson, S. C. (2011). The senses in language and culture. The Senses and Society, 6(1), 5-18.

17. Matthen, M. (2015). The individuation of the senses.

18. Mberamihigo, F. (2014). L'expression de la modalité en kirundi. Exploitation d'un corpus électronique.

19. Moravcsik, E. A. (2012). Introducing language typology. Cambridge University Press.

20. Polis, S. (2009). Interaction entre modalité et subjectivité en néo-égyptien. Autour de la construction mri+ iw circ." souhaiter que". Lingua Aegyptia, 17, 201-229.

21. Ritchie, I. (1991). Fusion of the Faculties: A Study of the Language of the Senses in Hausaland. The varieties of sensory experience, 192-202.

22. San Roque, L., Kendrick, K. H., Norcliffe, E., Brown, P., Defina, R., Dingemanse, M., Dirksmeyer, T., Enfield, N. J., Floyd, S., \& Hammond, J. (2015). Vision verbs dominate in conversation across cultures, but the ranking of non-visual verbs varies. De Gruyter Mouton.

23. San Roque, L., Kendrick, K. H., Norcliffe, E., \& Majid, A. (2018). Universal meaning extensions of perception verbs are grounded in interaction. Cognitive Linguistics, 29(3), 371-406.

24. Scott, M. (2016). WordSmith Tools Version 7.0. 0.54. Oxford: Lexical Analysis Software.

25. Sweetser, E. (1990). From etymology to pragmatics: Metaphorical and cultural aspects of semantic structure (Vol. 54). Cambridge University Press.

26. Sweetser, E. (1991). From etymology to pragmatics : Metaphorical and cultural aspects of semantic structure (Vol. 54). Cambridge University Press.

27. Usoniene, A. (1999). Perception verbs revisited. WORKING PAPERS-LUND UNIVERSITY DEPARTMENT OF LINGUISTICS, 211-225.

28. Usonienè, A. (2002). Types of epistemic qualification with verbs of perception. Kalbotyra, 52, 147154. 
29. Vanhove, M. (2008). Semantic associations between sensory modalities, prehension and mental perceptions. From polysemy to semantic change: Towards a typology of lexical semantic associations, 341-370.

30. Viberg, \AAke. (1983). The verbs of perception : A typological study. Linguistics, 21(1), 123-162.

31. Viberg, \AAke. (1984). The verbs of perception: A typological study. Explanations for language universals, 123-162.

32. Wierzbička, A. (1980). Lingua Mentalis. The semantics of natural language.-Academic Press, Sydney.

\section{AUTHOR}

Emmanuella Ahishakiye holds an MA. Double Degree in Linguistics and Its Applications for a Multilingual Society (LAMUSO) earned at Université Catholique de Louvain (Belgium) and Oslo University (Norway). As of her career, she works as an Assistant Lecturer at the University of Burundi -Institute for Applied Pedagogy since 2012. Emmanuella is currently interested in lexical semantics, where for her PhD project (University of Burundi- University of Liège) she works on the semantics of Perception verbs in Kirundi and their implications on second/foreign languages learning and teaching.

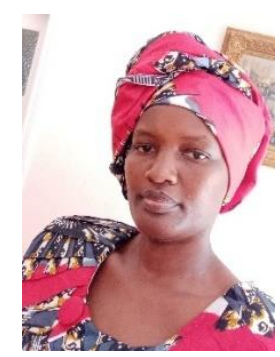

(C) 2021 By AIRCC Publishing Corporation. This article is published under the Creative Commons Attribution (CC BY) license. 